\title{
PUBLIC OPINION SURVEY ABOUT CONSUMPTION OF CEREALS AND THEIR PRODUCTS IN THE REPUBLIC OF MACEDONIA AND THE REPUBLIC OF BULGARIA
}

\author{
Gjore Nakov ${ }^{1}$, Nastia Ivanova ${ }^{1}$, Tzonka Godjevargova $^{2}$ \& Stanka Damyanova ${ }^{1}$ \\ 'University od Ruse "Angel Kanchev", Branch Razgrad \\ blv. Aprilsko Vastanie,47, e-mail: gnakov@uni-ruse.bg \\ 2 University "Prof. Dr. Assen Zlatarov", Burgas
}

Prof. Yakimov Street 1, Burgas 8010, Bulgaria, e-mail: godzevargova@yahoo.com

\begin{abstract}
Cereals in nutrition provide the energy necessary for daily functions and usual metabolic processes. Apart from being used as basic raw material in beer and whisky production, barley is more often used in baking industry through fortifying wheat products or through complete replacement of wheat flour with barley flour. Triticum monococcum L. is a wild wheat whose interest for cultivation rises due to dietetic nutritive aspects of this particular type of wheat, mainly because of the important role in preventing cancer, diabetes and chronic diseases. The aim of this abstract is to assess the knowledge and attitudes of consumers in the Republic of Macedonia and the Republic of Bulgaria regarding the consumption of cereals in daily nutrition and products from different cereals.
\end{abstract}

Keywords: cereals, public opinion, Republic of Macedonia, Republic of Bulgaria.

\section{INTRODUCTION}

Eating habits and trends in production and consumption of food have health, ecological and social influences. European Union fights the characteristics of modern diseases such as: obesity, osteoporosis, cancer, diabetes, allergies and teeth problems. Developed countries also confront problems related to aging of the population, using energy-boosting food and non-balanced diet [1].

Food which has positive effects on people's health contains ingredients which help in specific functioning of the body. Simply, food is fuel which provides the energy necessary for daily functions and normal metabolic processes [2]. Although wheat is considered a good source of calories and other nutritives, it is nutritionally poor as proteins in cereals are poor with essential amino acids such as lysine and threonine. Therefore, the complete or partial substitute of wheat with cheap raw materials helps to improve the nutritive quality of wheat products [3]. The purpose of this abstract is to analyse the consumption of cereal products by people in the Republic of Macedonia and the Republic of Bulgaria, as well as their knowledge about the use of barley and Triticum monococcum in baking industry.

\section{MATERIAL AND METHODS}

For achieving the goal of this abstract, a survey was made which was completed by 109 people from the Republic of Macedonia (67\% female and 33\% male). The age limit of people completing the survey is the following: $11.9 \%$ under 20 years old, $45.9 \% 21-30$ years old, $20.2 \%$ from 31 to 40 years old, $19.3 \%$ from 41 to 50 years old and $2.8 \%$ from 51 to 60 years old. The education which they have or are going to achieve (whereas in process of achieving) is the following: $60.6 \%$ high education, $34.9 \%$ secondary education and $4.6 \%$ Doctor of Science. In the Republic of Bulgaria, the survey was completed by 146 people

IRTIIE Vol. 6, No. 1, 2018 ISSN 1314-8788 (print), ISSN 1314-8796 (online), doi: 10.15547/artte.2018.01.010 


\section{ART'TE $Y$}

Ipplied Resseirl'hes in Teednicis, Technologies and Bductition Journal of the Faculty of Technics and Technologies, Trakia University https://sites.google.com/a/trakia-uni.bg/artte/

( $81.5 \%$ female and $18.5 \%$ male). The age limit of people who completed the survey is: $6.2 \%$ under 20 years old, $32.2 \% 21-30$ years old, $28.8 \%$ from 31 to 40 years old, $26 \%$ from 41 to 50 years old, $5.5 \%$ from 51 to 60 years old and $1.4 \%$ over 60 years old. The education which they have or are going to achieve (whereas in process of achieving) is: primary education $1.4 \%, 26 \%$ secondary education, $68.5 \%$ high education and $4.1 \%$ Doctor of Science.

\section{RESULTS AND DISCUSSION}

Cereal products such as biscuits, crackers and cereals for breakfast are a dominant source of energy for people's diet, especially for children consuming cereals [4]. The answers to the question "Do you eat cereals?" are shown in Figure 1.

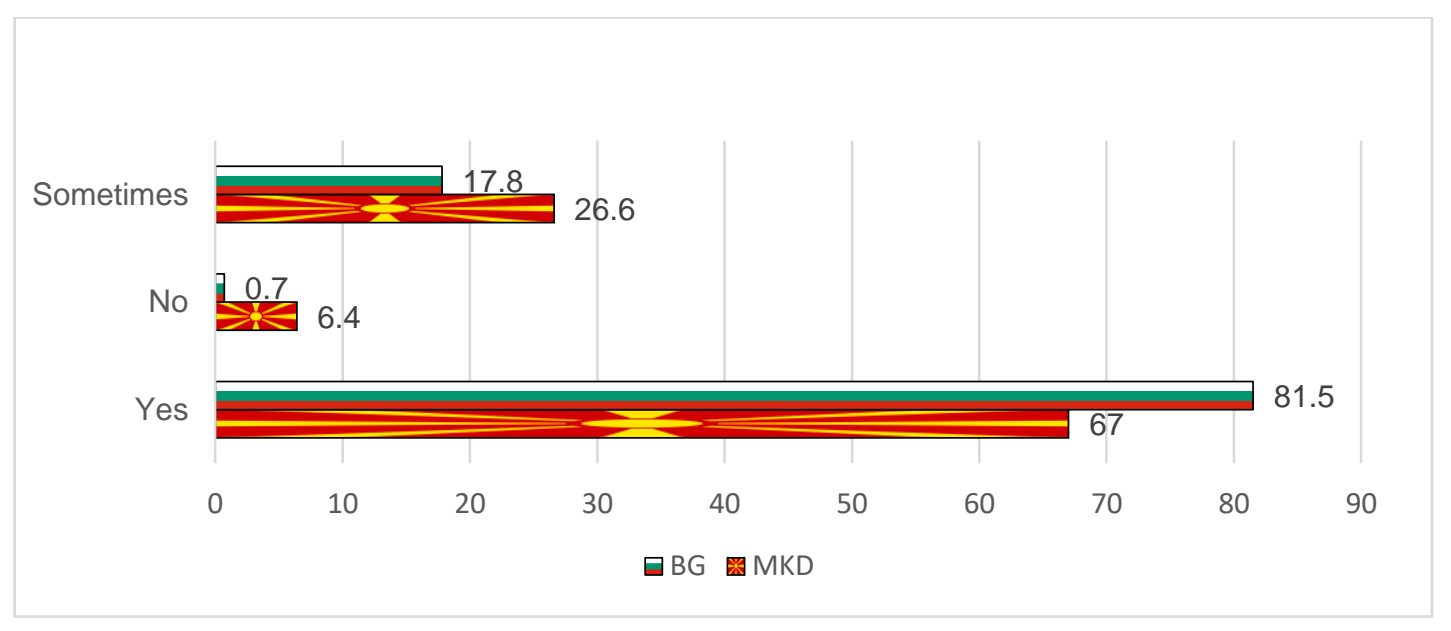

Figure 1. Answers to the question "Do you eat cereals?"

From Figure 1 it can be seen that respondents in Macedonia (81.5\%) as well as in Bulgaria $(67 \%)$ use cereals in their nutrition. The answer "sometimes" was given by $17.8 \%$ respondents in Macedonia and $26.6 \%$ in Bulgaria, while the answer "no" was given by $0.7 \%$ in Macedonia and $6.4 \%$ by the respondents in Bulgaria. Reasons why respondents answered "no" to the previous question are shown in Figure 2.

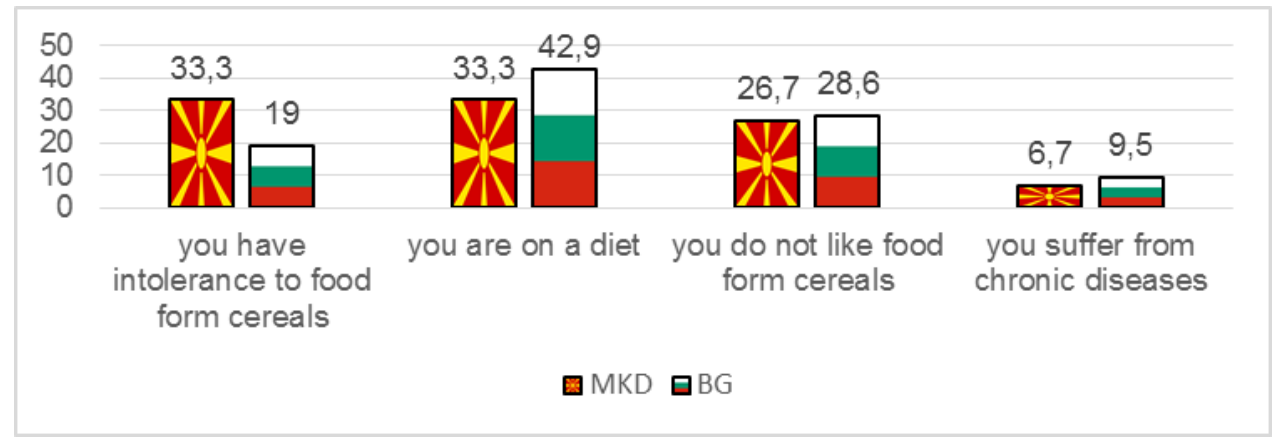

Figure 2. Possible reasons for not using cereals

From Figure 2 it can be seen that respondents in the Republic of Bulgaria do not use cereals because they are on a diet (42.9\%), then, $28.6 \%$ respondents answered that they do not like food from cereals, $19 \%$ are intolerant to this type of food, and only $9.5 \%$ of the respondents

IRTIIE Vol. 6, No. 1, 2018 ISSN 1314-8788 (print), ISSN 1314-8796 (online), doi: 10.15547/artte.2018.01.010 


\section{ARTTIE $Y$}

Ipplied Resseirlohes in Technics, Technologies and Bductation

Journal of the Faculty of Technics and Technologies, Trakia University https://sites.google.com/a/trakia-uni.bg/artte/

answered that they suffer from chronic diseases. On the other hand, respondents in the Republic of Macedonia do not usually consume cereals because they are on a diet $33.3 \%$ and because they are intolerant to this type of food $33.3 \%, 28.6 \%$ of the respondents said that they do not like this type of food, and $6.7 \%$ do not use cereals because of chronic diseases.

The answers of the respondents in the Republic of Macedonia and the Republic of Bulgaria to the question "What do you usually consume from the food from cereals?" are given in Figure 3.

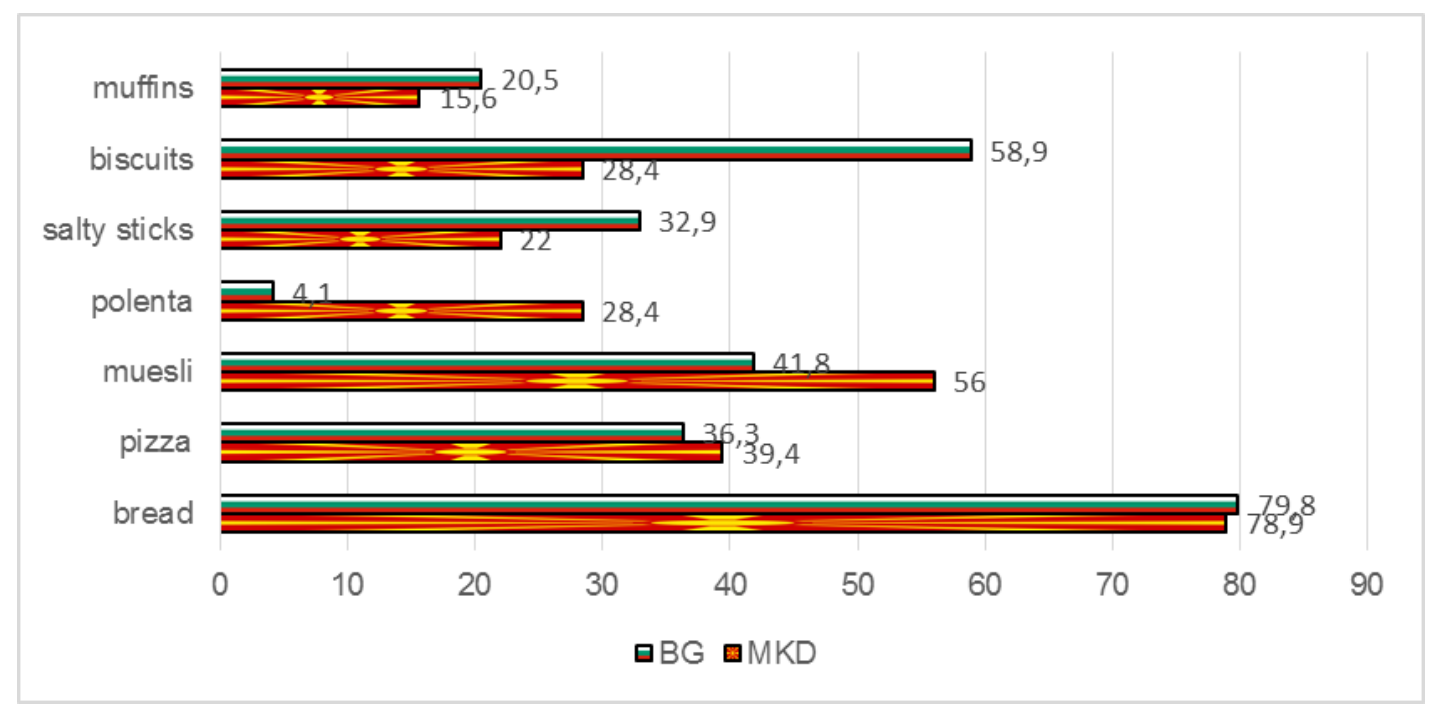

Figure 3. Answers to the question "What do you usually consume from the food from cereals?" (you can give multiple answers)

From Figure 3 it can be seen that in Macedonia, as well as in Bulgaria, bread is the most consumed food made from cereals $(79.8 \%$ and $78.9 \%$ appropriately). Bread is one of the basic fundamental foods which is necessary in people's diet. It is a product made from flour, water and other additives [5]. Dhingra and Jood quoted by Noorfarahzilah M. et. al. (2014) point out to the fact that bread can be made by replacing $15 \%$ of wheat flour with barley flour and produce organoleptic acceptable bread with satisfying level of proteins, lysine, dietary fiber, $\beta$-Glucans and minerals. $\beta$-Glucans regulate the blood cholesterol and the level of glucose in blood [3].On the other hand, second product made from cereals, usually consumed by respondents in the Republic of Bulgaria is biscuits $(58.9 \%)$. They can be a good candidate for functional products by using raw materials with established functional properties in their recipe structure. Moreover, biscuits are popular, every day consumed products which can last for a long time [6]. Unlike them, the answers to respondents in the Republic of Macedonia is muesli which is the second mostly consumed product from cereals $(56 \%)$. Constant consumption of food made from whole grain (whole meal) flour is related to the reduce of people's mortality [7].

In the last few years, opinions of consumers about nutritive aspect of food and proper nutrition increase. Therefore, consumers care more about balanced and healthy nutrition. Moreover, consumers pay more attention to the label of food products searching for information whether the chosen food is safe and quality [8].

Answers of the respondents to the question "Is it important for you to have proper information about the ingredients and energy value of biscuits?" are shown in Figure 4. 


\section{ARTTIE $Y$}

Ipplied Reserertches in Technics, Technologies and Bduration Journal of the Faculty of Technics and Technologies, Trakia University https://sites.google.com/a/trakia-uni.bg/artte/

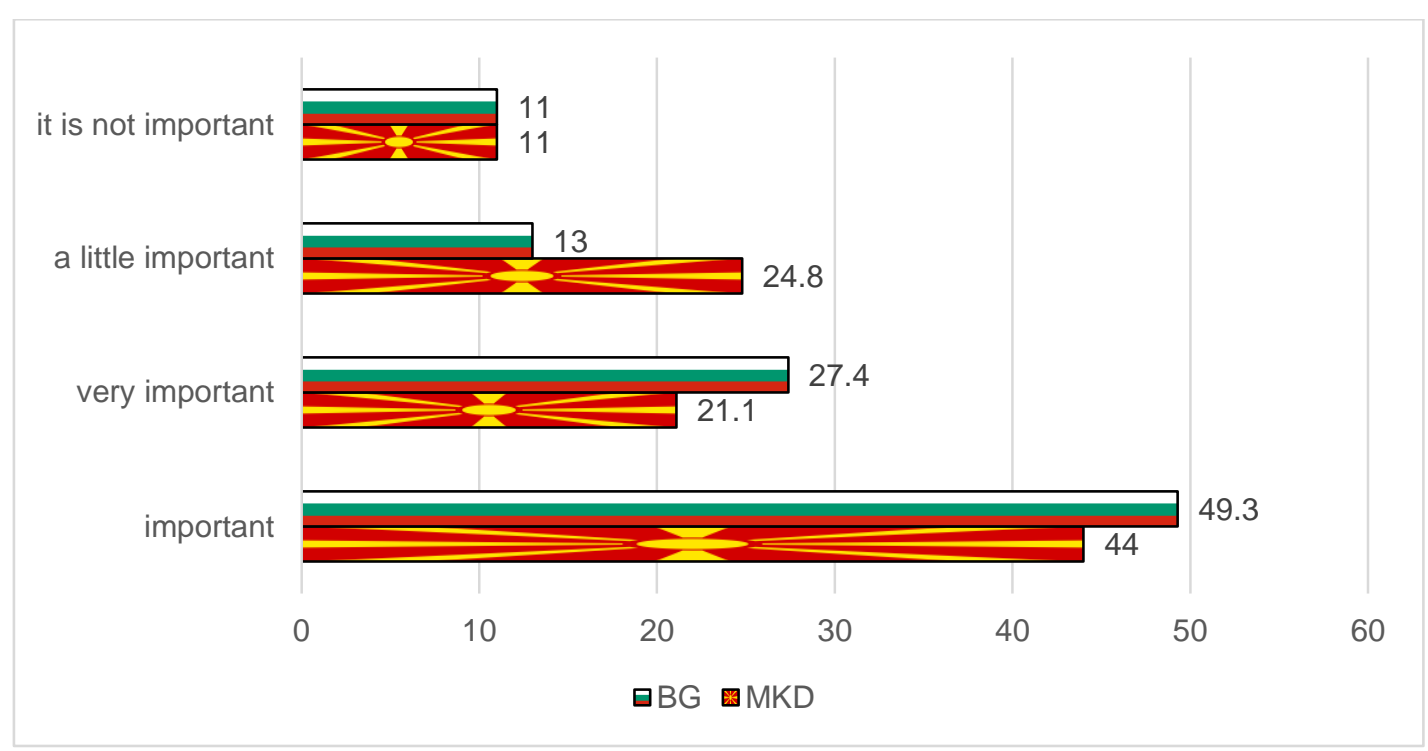

Figure 4. Answers to the question "Is it important for you to have proper information about the ingredients and energy value of biscuits?"

From Figure 4 it can be seen that it is important for all respondents to have proper information about the ingredients and energy value of the biscuits. The same per cent of the respondents $(11 \%)$ answered that the information about ingredients and energy value of biscuits is not important. Nakov Gj. et al. (2017) in their survey asked from customers to also classify the information given on the label, thus the most important information according to customers was the validity of the product, and the least important was the amount of salt [8]. Cereals are members of the large monocotyledonous grass family, the Gramineae [9]. Fig. 5 shows the answers of the respondents in the Republic of Macedonia and the Republic of Bulgaria to the question "Do you think that whole meal products (products from whole wheat grain) have positive effect on Your health?"

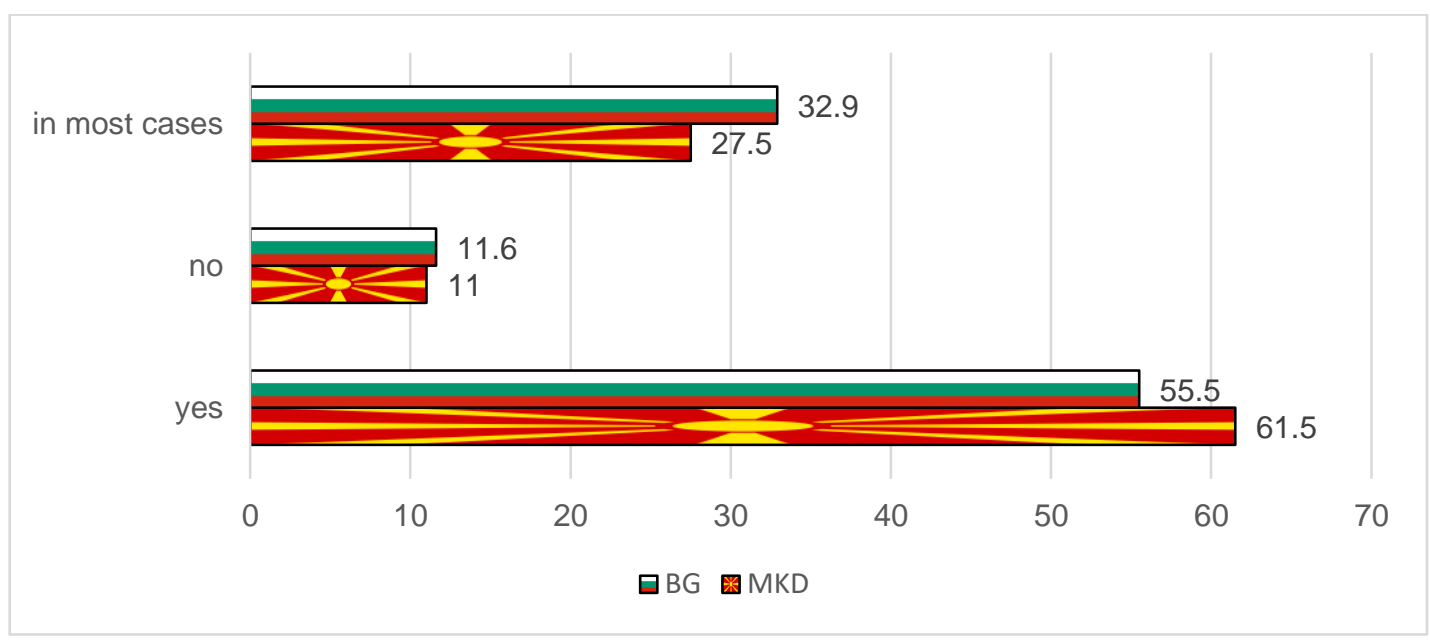

Figure 5. Answers to the question "Do you think that wholemeal products (products from whole wheat grain) have positive effect on Your health?" 


\section{IRITIE}

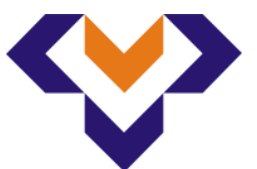

Ipplied Resseirlohes in Technics, Technologies and Bductation

Journal of the Faculty of Technics and Technologies, Trakia University https://sites.google.com/a/trakia-uni.bg/artte/

From Figure 5 it can be seen that $55.5 \%$ of respondents in Bulgaria and $61.5 \%$ respondents in Macedonia consider that wholegrain products have a positive effect on people`s health.

In materials used for analyzing people's opinion about products from cereals the question "Would you buy biscuits which can lower the risk of certain illnesses when consumed regularly?" was asked. The answers are shown in Figure 6.

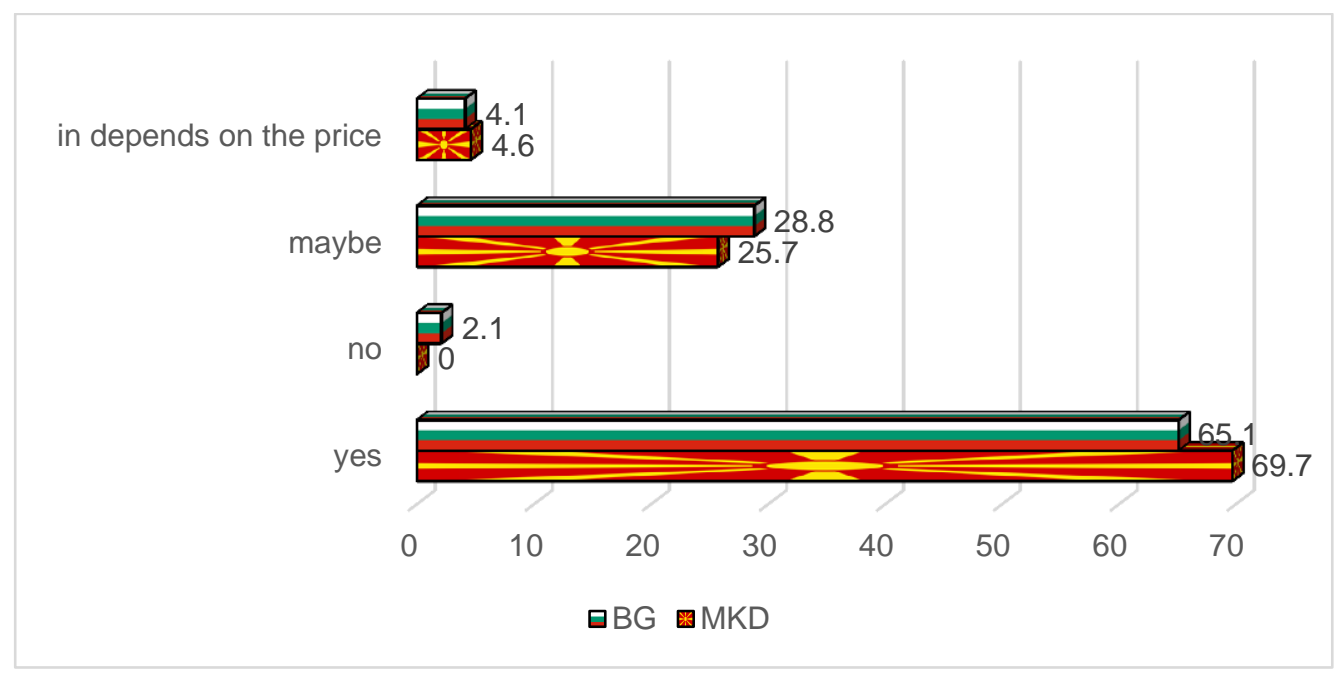

Figure 6. Answers to the question "Would you buy biscuits which can lower the risk of certain illnesses when consumed regularly?"

From the shown results in Figure 6 it can be seen that the respondents in Macedonia $(69.7 \%)$ as well as in Bulgaria (65.1\%) answered affirmatively, $4.5 \%$ (in Macedonia) and $4.1 \%$ (in Bulgaria) answered depending on the price.

Barley grain belongs to the family of Poaceae, Triticeae и Hordeum tribe. The whole amount of grown barley is Hordeum vulgare. Barley (Hordeum vulgare) is a cereal which was used for making bread even in the Neolithic age. It is considered that firstly, it was grown in the Southwestern part of Asia or North Africa, while wild forms of barley (Hordeum spontaneum) can still be found in Western Asia [10]. The answers to the question what is barley used for are shown in Figure 7.

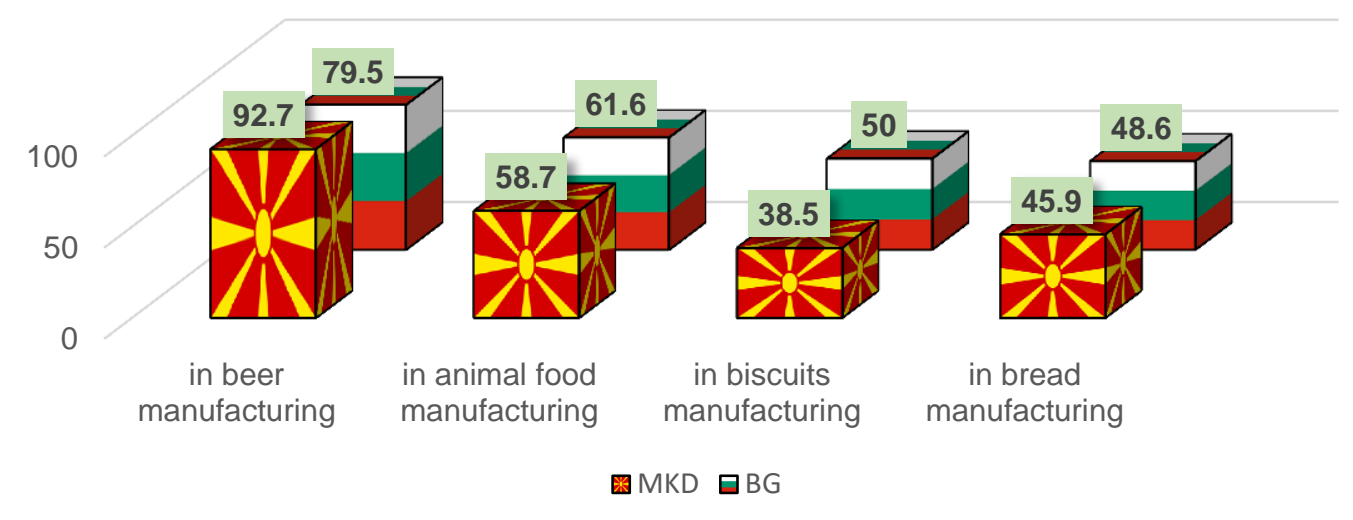

Figure 7. Answers to the question "What is barley used for?"

IRTIIE Vol. 6, No. 1, 2018 ISSN 1314-8788 (print), ISSN 1314-8796 (online), doi: 10.15547/artte.2018.01.010 


\section{AR'T'TE

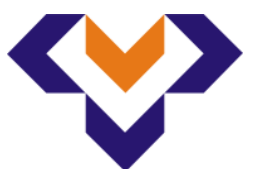 \\ Ipplied Researthes in Technics, Technologies and Bduration \\ Journal of the Faculty of Technics and Technologies, Trakia University https://sites.google.com/a/trakia-uni.bg/artte/}

From answers shown in Figure 7 it can be seen that respondents mostly answered "in beer manufacturing" (in Macedonia 92.7\%, in Bulgaria 79.5\%). Minority of respondents in Macedonia (38.5\%) consider that barley can be used in the biscuit manufacturing, whereas in Bulgaria minority of respondents (48.6\%) consider that barley can be used in the bread manufacturing.

Einkorn wheat (Triticum monococcum L.) is one of the oldest cereals suitable for organic agriculture. Compared to other cereals, Einkorn wheat is more resistant to diseases and can survive drier climate. Today, Einkorn wheat is grown only on the sides of the Mediterranean, but there is an increased interest for growing this culture again due to the more common science statements about dietary and nutritional aspects of this type of wheat, mostly its important role in the prevention of cancer, diabetes and chronic diseases [11]. The answers to the question "What type of cereal is Triiticum monoccocum?" are shown in Figure 8.

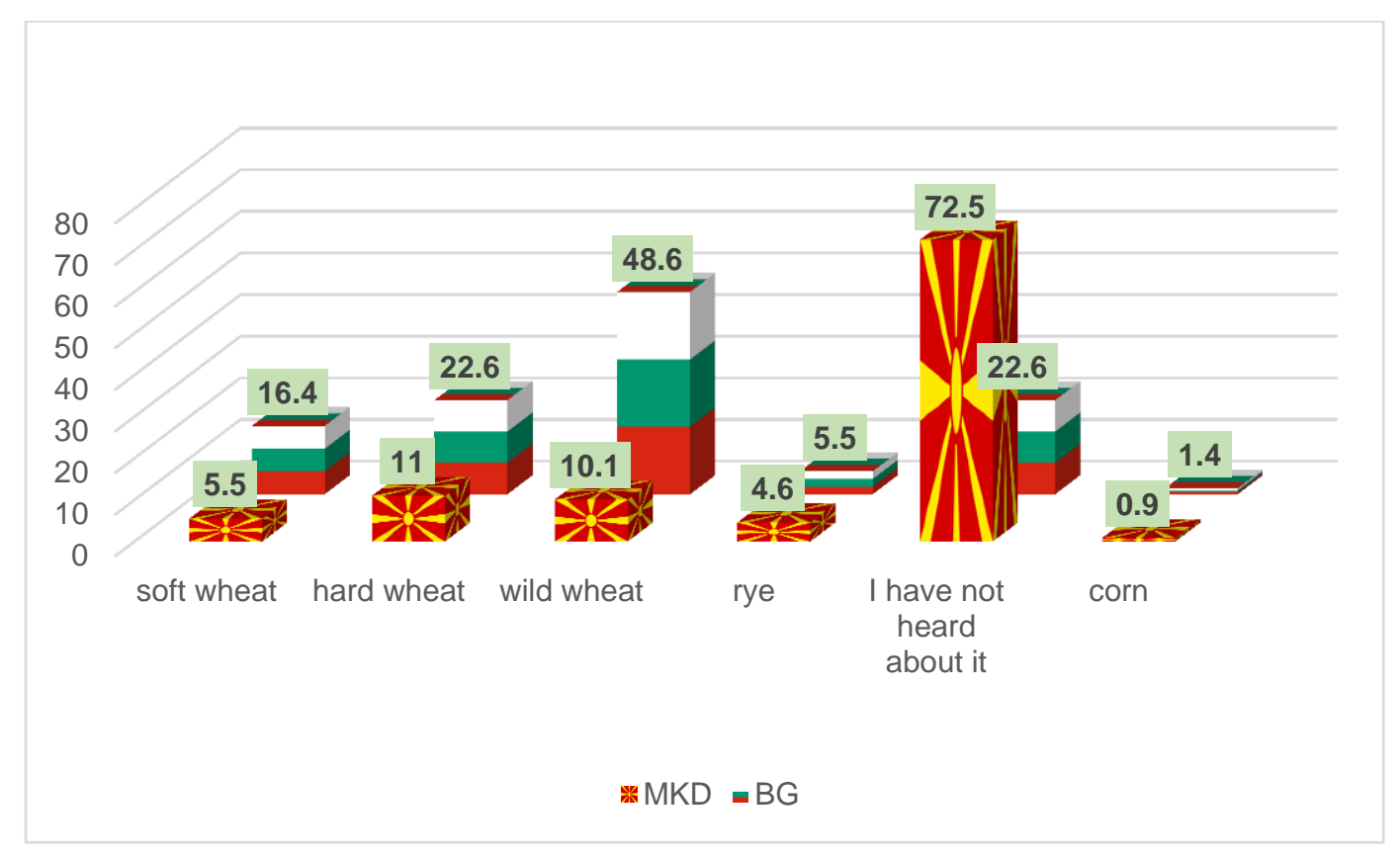

Figure 8. Answers to the question "What type of cereal is Triiticum monoccocum?"

From the shown answers in Fig. 8 it can be seen that even $72.5 \%$ from the respondents in the Republic of Macedonia have not heard about this type of cereal. This is because even if this type of cereal can be found on the market in the Republic of Macedonia, people are not informed about it. On the other hand, Triiticum monoccocum wheat is present on the market in the Republic of Bulgaria and its use is more and more intensified.

\section{CONCLUSION}

From the conducted social analysis in the Republic of Macedonia and the Republic of Bulgaria it was determined that most of the respondents from both countries consume cereals, and majority of those who do not consume cereals in the Republic of Macedonia stated that they are intolerant to this type of food, whereas in the Republic of Bulgaria, most of the respondents do not consume cereals due to being on a diet. In both countries, bread is mostly consumed as a product from cereals. Regarding the importance of the information about energy value and ingredients of the products, the respondents stated that it is important for them to have proper information. Respondents consider that wholegrain

IRTIIE Vol. 6, No. 1, 2018 ISSN 1314-8788 (print), ISSN 1314-8796 (online), doi: 10.15547/artte.2018.01.010 


\section{ARTIIE

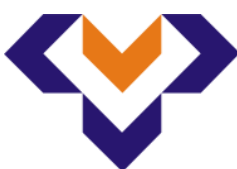 \\ Ipplied Resseirl'hes in Teednicis, Technologies and Bductition \\ Journal of the Faculty of Technics and Technologies, Trakia University https://sites.google.com/a/trakia-uni.bg/artte/}

products have a positive effect on people's health, and when buying biscuits, respondents would mostly buy biscuits which can lower the risk of certain illnesses when consumed regularly. In both countries, respondents have knowledge that barley is used in the beer manufacturing, minority of the respondents in the Republic of Macedonia consider that barley can be used in biscuits manufacturing. Most of the respondents from the Republic of Macedonia have not heard about the Triiticum monoccocum cereal, which is due to the absence of this type of wheat on the market, whereas in the Republic of Bulgaria this type of wheat is already present on the market and has bigger and bigger use.

\section{REFERENCES}

[1] Cencic A., Chingwaru W. (2010). The Role of Funcitonal Foods, Nutraceuticals, and Food Supplements in Intestinal Health, Nutritients (2) pp. 611-625.

[2] El Sohaimy A. S. (2012). Functional Foods and Nutraceuticals-Modern Approach to Food Science, World Applied Sciences Journal 20 (5) pp. 691-708.

[3] Noorfarahzilah M., Lee J. S., Sharifudin M. S., Moht Fadzelly A. B., Hasmadi M. (2014). International Food Research Jourinal 23 (6) pp. 2061-2074.

[4] Simpson K. B. (2012). Food Biochemistry and Food Processing (second edition), A John Wiley \& Sons, Ltd., Publication.

[5] Akanbi T. C., Ikujenlola V. A. (2016). Croat.J.Food Sci.Technol. 8 (1) pp.1-9.

[6] Pasqualone A., Bianco A.M., Paradiso M.V., Summo C., Gambacorta G., Caponio F., Bianko A. (2015). Production and characterization of functional biscuits obtained form purple wheat, Food Chemistry 180, pp. 64-70.

[7] Dean M., Sherherd R., Arvola A., Vassallo M., Winkelmann M., Claupein E., Lahteenmaki L., Raats M. M., Saba A. (2007). Consumer perceptions of healthy cereal products and production methods, Journal of Cereal Science (46) pp.188-196.

[8] Nakov Gj., Ivanova N., Damyanova S., Stamatovska V., Necinova Lj. (2017). Public opinion surveys of consumers for manner of labelling the food products in the Republic of Macedonia, Ukrainian Food Journal, Vol. 6 (1) pp.154-164.

[9] Morris C. P., Bryce H. J. (2000). Cereal biotechnology, (2000), Woodhead Publishing Limited and CRC Press LLC.

[10] Ullrich E. S., Baik K. B., Quinde-Axtell Z., Nair S. (2008). Barley for food: traits and improvements Proceedings of the 10th International Barley Genetics Symposium, Alexandria, Egypt, pp. 563-575.

[11] Nakov Gj., Stamatovska V., Necinova Lj., Ivanova N., Damyanova S. (2016). Nutritional Properties of Einkorn Wheat (Triticum Monococcum L.) - Review, 55-th Science Conference of Ruse University, Bulgaria, Reports Awarded with "Best Paper" Crystal Prize, pp. 381-384. 